\title{
Remarks on the History of the Navy of the Empire of Nicaea in the Light of the Chronicle of Georgios Akropolites
}

\author{
Marcin Böhm \\ The University of Opole, ul. Strzelców Bytomskich 2, 45-084 Opole, Poland \\ mabohm@wp.pl
}

\begin{abstract}
Keywords: The Empire of Nicaea, John III Doukas Vatazes, Georgios Akropolites, Byzantine Navy, Venice
\end{abstract}

\begin{abstract}
The Empire of Nicaea was a successor of the Byzantium shattered in 1204. In the newly established state marine traditions of Byzantines, remain alive. The best testimony to this, are the evidence contained in the chronicle of Georgios Akropolites, devoted to activities of the rulers of Nicaea, aimed to build their own naval forces. In this paper I'll also try to answer, where was beating the heart of the Nicean shipbuilding industry and how large was the navy of this state. This is important from point of view of the maritime history, because of the fleet of the Empire of Nicaea, filled the gap created after the fall of Constantinople and the Byzantine Empire, which was the local naval power in previous centuries. Akropolites give us a clear and direct answer to a question, where we should search for a center of Nicaean shipbuilding industry. Georgios Akropolites suggest us, that was in two towns, Holkos and Smyrna. The above-mentioned fleet consisted of the few squadrons, each counting 5-6 ships. We can only guess that a fleet of the John III, could count about 50 warships, whose quality was worse to that belonging to the Venetians. We must say that the fleet of the Empire of Nicaea, which we see in the chronicle of Akropolites, was the force, that lent itself to the support of ground forces. And in this role worked well. The situation was different when it comes to clashing with the Venetians, with the experienced crews of their ships, who surpassed Nicaean in this matter. Even with the advantage of numbers, Nicaean was unable to overcome at the sea, the citizens of the Republic of St. Mark. The plan to build their own naval forces, which was taken by the emperors of Nicaea, was a good direction.
\end{abstract}

\section{Introduction}

This paper was presented on the 23td International Congress of Byzantine studies, Belgrade, August 22-27, 2016 in the form Some Remarks on the History of the Navy of the Empire of Nicaea in the Light of the Chronicle of Georgios Akropolites. The Empire of Nicaea was the successor state of the Byzantine Empire and was founded after the IV Crusade by the Laskaris family. The History of the Empire of Nicaea lasted only from 1204 to 1261 when Michael Palaiologos recovered Constantinople. In Nicaea, among the relics of the Byzantine world, also survived the Byzantine maritime tradition. The Emperor's from Nicaea created their own naval forces on the East Coast of the Aegean Sea. So far, historians didn't give this problem enough attention. Only in old works of Helen Ahrweiler [1], Michael Angold [2] and recently published an English translation of Akropolites Chronicle [3], done by Ruth Macrides, we found some studies concerning this topic. The main objectives of this paper are to show, an account of Nicaean statesman, chief-in-command, and historian, Georgios Akropolites (1217 or 1220-1282), about the role of the fleets of the Empire of Nicaea. What do we know about this author? Akropolites was born in 1217 in Constantinople, to the family of a high court official. In 1233 he was sent by his father to the court of the Emperor of Nicaea. In the rank of the great logothete, he took part in the expedition of the Emperor John III Vatatzes (1193-1254) at Thessalonica. In 1261 he returned to Constantinople, which was liberated from the Latins. He was an imperial envoy to the Pope Gregory X (1210-1276). Akropolites participated in the Second Council of Lyons, and on 6 July of 1274, as chairman of the delegation of the Byzantines, he filed oath on behalf of the Emperor's, under which he recognized not only the papal primacy but also the dogmas of the Roman Church. He was therefore extremely well 
informed about the affairs of state, including the activities of the naval forces. Thanks to his position on the court, his chronicle is, therefore, a very valuable and reliable historical source.

In this paper I'll also try to answer, where was beating the heart of the Nicean shipbuilding industry and how large was the navy of this state. This is important from point of view of the maritime history, because of the fleet of the Empire of Nicaea, filled the gap created after the fall of Constantinople and the Byzantine Empire, which was the local naval power in previous centuries. I was working on the Greek, critical edition of Georgios Akropolites Chronicle, done by A. Heisenberg, and later reworked by P. Wirth [4].

\section{Results and Discussion}

Georgios Akropolites for the first time mentioned the fleet of the Empire of Nicaea in paragraph 22, of his chronicle. This information is connected with operations of the emperor John III Doukas Vatazes, against Venetians in 1220-1230. In this decade, that emperor built his warships-

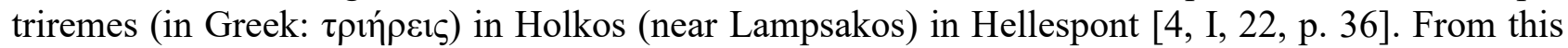
port John III attack on towns Madyta, Kallipolis and coastal areas on Chersonesos, subjected to Venetians [4, I, 22, p. 36; 5]. So, Holkos was a forward base for Nicaean fleet in Hellespont, and a great place to set a trap on ships of both Venetians and other Latins, in straits between Europe and Asia Minor. The Second port of Nicaean navy in Hellespont, as we see in work of Akropolites, was a Lampsakos. In this role is mentioned in paragraph 23, when John III went to this town, and destroyed with fire his own ships, to prevent them from fall in the hands of Venetians [4, I, 23,4-5, p. 37]. Attack of Venetians on Lampsakos was well connected with the action of John of Brienne (pp.1175-1237) directed against emperor John III [5,6]. John of Brienne during this military operation (1233) landed in Lampsakos area and conquered Holkos, Lampsakos and other important port of Nicaean, Pegai, where he left garrison for one year [5,6, 7]. Just before an attack of John of Brienne on Lampsakos, in 1233 the emperor John III sent a fleet, under command of megas domestikos Andronikos Palaiologos, against Rhodes [4, I, 28, pp. 45-46]. Later, we have other information about fleet and Lampsakos, written in paragraph number 33, of the Akropolites Chronicle. In 1235 Emperor John III crossed the Hellespont from Lampsakos and finally captured on the Venetians town Kallipolis [4, I, 33, p.50]. The first largest fragment of a chronicle, concerning the Nicaean navy, we have in paragraph 37. In 1240, during the siege of Tzouroulos by the Venetians, John III built other fleet consisting of several triremes [4, I, 37,4-6, p. 59]. That fleet had an inexperienced crew and was first under command of Manuel Kontophre, who was later replaced by Iophre the Armenian [4, I, 37,14-22, p. 59]. Manuel lost his position, as he openly opposed the emperor, suggesting that his ships, even with the significant advantage over the enemy, are much worse than the ships of the Venetians [4, I, 37,14-22, p. 59]. Iophre had 30 triremes in his fleet, and throw them foolishly on Venetians [4, I, 37,23, pp. 59-60]. The Enemies of Nicaean have only 13 ships, but Iophre lost the battle and 13 of his ships [4, I, 37,23, pp. 59-60]. Other sources state, that this battle had taking place in May-June 1241, and Venetians have 16 ships, which have won against 25 ships of Nicaean (who lost 10 of them). It is worth quoting at this point the source in the original Latin notation: Anno ducis xiii ${ }^{\circ}$ Iohanes Vatacius, qui Federici imperatoris filiam sibi copulaverat, cum galeis XXV et alliis navigiis per mare, et cum multitudine copiosa equitum et peditura in terram, urbem obsedit: Tunc lohanes Michael, pro Venetis potestas Constantinopolita'nus, armatis xvi galeis, egrediens, Grecos bello agreditur, et decem illorum galeas, reliquia fugatis cepit, et sic civitas ab obsidione liberator [3, p. 206, note 18; 8].

So important data about Nicaean Navy, we find next, an end of paragraph 48. In 1249 emperor John III organized a new fleet in Aegean town, Smyrna [4, I, 48, p. 87]. There, he prepared

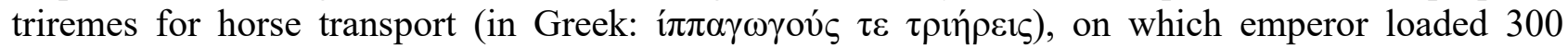
horses [4, I, 48, p. 87]. This fleet was under command of probestos Theodore Kontostephanos and was sent on Rhodos, where Nicaean won, against the Genoese, who occupy this island [4, I, 48, pp. 87-88]. Later in the chronicles, we see only minor episodes, which we can associate with the Nicaean fleet. The First is related to the person of Manuel Komnenos Dukas. Emperor John III gave to this man 6 triremes and send him to Great Vlachia [4, I, 38, 22-23, p.61]. Another episode we 
find, during the actions of basileus in the Balkans, when Manuel Kontophre returns as a commander of triremes [4, I, 40, 13-15, p. 66]. The Lampsakos also is listed many times, as the place of residence of the emperor, or the place from where he exceeds the Hellespont, heading for Europe [4, I, 41, 18, p.68; I, 49, 16, p. 89; I, 60, 1-2, p. 124; I, 83, p.173; I, 84, p. 179].

\section{Conclusion}

As we see above, Akropolites give us a clear and direct answer to a question, where we should search for a center of Nicaean shipbuilding industry. Georgios Akropolites suggest us, that was in two towns, Holkos and Smyrna [3, p. 99]. Holkos under the authority of the Nicaeans, probably took place of other important port in Hellespont, Abydos, which was previously the gateway to the Aegean Sea and one of the significant ports in the Byzantine Empire [9]. Holkos together with later gained Kalliopolis, played the same role as Abydos, except, that they guarded the entrance to the Sea of Marmara. Smyrna since times of Alexios I Comnenos (1081-1118), was a strategic Byzantine port and an important center of shipbuilding industry $[10,11,12,13]$. These two towns did not have as great port facilities, as Constantinople. Therefore, in the long run, they would not be able to maintain similar fleets, as such of those which was possessed by Byzantines in the twelfth century. How great, then, were the naval forces of the Empire of Nicaea, in light of words of Akropolites? Akropolites mentioned that Iophre the Armenian had 30 triremes under his command. That ships probably came from Lampsakos area and they operated only on the Sea of Marmara. Another mention on this subject is information about 300 horses loaded onto triremes. We know, thanks to work of John Pryor, that on this kind of ship, could be loaded around of 12 horses [14]. Dividing the above-mentioned number of horses by 12, we get the number of 25 ships. Such a size of the fleet of Nicaean, Venetian sources also attribute to the fleet of Iophre the Armenian. Later Akropolites also mentions the six ships sent together with Manuel Komnenos Dukas. We can, therefore, speculate, that the above-mentioned fleet consisted of the few squadrons, each counting 5-6 ships. We can only guess that a fleet of the John III, could count about 50 warships, whose quality was worse to that belonging to the Venetians.

Akropolites does not say this so explicitly, but the main purpose of these fleets, off the support activities to ground forces aimed at the recovery of the Constantinople, was to recover the sea lanes leading from the Rhodes to the Sea of Marmara. We know from other Greek sources, that John III conquered during his reign island on the Aegean Sea: Chios, Samos, Lesbos, Kos, Icaria, and Rhodes [15]. The Akropolites analysed by us is only interested in the issue of subordination of the island of Rhodes. This is understandable, because as we said earlier, from this island was running the trail, the sea route along the west coast of Asia Minor, towards the Hellespont.

In closing words of our conclusions, we must say that the fleet of the Empire of Nicaea, which we see in the chronicle of Akropolites, was the force, that lent itself to the support of ground forces. And in this role worked well. The situation was different when it comes to clashing with the Venetians, with the experienced crews of their ships, who surpassed Nicaean in this matter. Even with the advantage of numbers, Nicaean was unable to overcome at the sea, the citizens of the Republic of St. Mark. The plan to build their own naval forces, which was taken by the emperors of Nicaea, was a good direction. However, it was abandoned after 1261 and the recovery of Constantinople, for the benefit of the another sea alliance with the Genoese.

\section{References}

[1] H. Ahrweiler, Byzance et la Mèr, Paris, France, 1966, pp. 301-327.

[2] M. Angold, A Byzantine government in exile: government and society under the Laskardis of Nicaea, 1204-1261, London, 1975, pp. 196-200.

[3] R. Macrides, George Akropolites, The History, Translated with an Introduction and Commentary by Ruth Macrides, Oxford Studies of Byzantium, Oxford University Press, 2007, pp. 100-101. 
[4] A. Heisenberg ed., Georgii Akropolitae Opera, vols. I-II, Stuttgart, Germany, 1978.

[5] D. Jacoby, The Venetian Presence in the Latin Empire of Constantinople (1204-1261): the Challenge of Feudalism and the Byzantine Inheritance 141-201, Jahrbuch der Osterreichischen Byzantinistik 43 (1993), p. 165.

[6] G. Perry, John of Brienne, King of Jerusalem, Emperor of Constaninople, pp. 1175-1237, Cambridge, 2013, p. 172.

[7] P. Lock, The Franks in the Aegean, 1204-1500, London-New York, 1995, p. 65; Jacoby, The Venetian, p. 165.

[8] Andreae Danduli ducis Venetiarum chronica pre extensum descripta, RIS XII/1, BolognaCittà di Castello, 1938-1942, p. 298, 10-14.

[9] A. Kažhdan, Abydos, in: The Oxford Dictionary of Byzantium, ed. Aleksander Kažhdan, New York, 1991, vol. 1, pp. 8-9.

[10] Annae Comnenae Alexias, ed. D.R. Reinsch, A. Kambylis, Corpus Fontium Historiae Byzantinae, vol. 40/1, Berlin, 2001, XI 5, 3, p. 336.

[11] A. Kažhdan, Smyrna, in: The Oxford Dictionary of Byzantium, vol. 4, pp. 1920-1921.

[12] A. Savvides, O Seltzukos emires tes Smyrnes Tzachas(Caka) kai oi epidomes tou sta mikroasiatika paralia, ta nesia tou anatoliku Aigaiote kai ten Konstantinopole, pp. 10811106, B', Chiaka Chronika 16 (1984), p. 61.

[13] M. Böhm, Flota i polityka morska Aleksego I Komnena (The Fleet and maritime policy of the Emperor Alexius I Comnenus), Kraków, Poland, 2012, pp. 144-145.

[14] J.H. Pryor, E.M. Jeffreys, The Age of Dromon, Leiden, Netherlands, 2006, p. 323.

[15] Nicephori Gregorae, Byzantina Historia, ed. L. Schopen, vol. I, Bonnae, 1829, pp. 28-29. 